\title{
The application of zinc fertilizer reduces Fusarium infection and development in wheat
}

\author{
Muhammed Alsamir ${ }^{1}$, Esraa Al-Samir ${ }^{2}$, T A Kareem ${ }^{3}$, Mohammed Abass ${ }^{4}$, Richard Trethowan ${ }^{1}$ \\ ${ }^{1}$ Plant Breeding Institute, Faculty of Agriculture and Environment, University of Sydney, 107 Cobbitty Road, Cobbitty, \\ NSW 2570, Australia \\ ${ }^{2}$ Biology Department, College of Science, University of Basra, Iraq \\ ${ }^{3}$ Collage of Agriculture Engineering Sciences, University of Baghdad, Iraq \\ ${ }^{4}$ Plant Protection, College of Agriculture, University of Basrah, Iraq
}

*Corresponding author: alsamir.hameed@sydney.edu.au

Abstract

Fusarium pseudograminearum and Fusarium graminearum commonly cause crown rot (FCR) and head blight (FHB) in wheat, respectively. Disease infection and spread can be reduced by the deployment of resistant cultivars or through management practices that limit inoculum load. Plants deficient in micronutrients, including zinc, tend to be more susceptible to many diseases. On the other hands, and zinc deficiency in cereals is widespread in Australian soils. Zinc deficiency may have particular relevance to crown rot, the most important and damaging Fusarium disease of wheat and barley in Australia. Four wheat genotypes; Batavia, Sunco and two lines from the International Maize and Wheat Improvement Center (CIMMYT) were tested for response to FHB and FCR under differing levels of $\mathrm{Zn}, 1$ and $2 \mathrm{~g} / \mathrm{kg}$ and its correlation with disease severity. Sunco and CIMMYT line 146 were previously rated resistant to crown rot and $\mathrm{Zn}$ efficient. Zn application $2 \mathrm{~g} / \mathrm{kg}$ soil enhanced resistance to FCR of the disease susceptible and $\mathrm{Zn}$ in-efficient in Batavia and 48 as its recorded 0.75 and 0.5 respectively compared to Sunco and CIMMYT line 146 as it recorded 0.2 and 0.3 respectively, but did not increase resistance to FHB. However, $\mathrm{Zn}$ application did enhance the resistance of $\mathrm{Zn}$ efficient genotypes to FHB. Results suggest that higher levels of $\mathrm{Zn}$ fertilization could reduce the expression of Fusarium diseases in wheat.

Keywords: Fusarium, crown rot, head blight, wheat, Zn efficiency.

Abbreviations: FCR_Fusarium crown rot, FHB_Fusarium head blight, Zn_zinc.

\section{Introduction}

Several fungal soil-borne plant pathogens belong to the diverse genus Fusarium; with high ability to cause serious diseases on important plant families. These diseases damage small-grain cereals by rotting seed, causing seedling death, infecting crowns and spikes. Additionally, the head blight, produces a toxin detrimental to humans and animals (Goral et al., 2019). A number of Fusarium species reported to be a true pathogen of crown rot (FCR) and head blight (FHB) such as the species of F. culmorum, F, avenaceum , F, poae and Microdochium nivale and induced a range of symptoms ranging from severe disease symptoms to only mild symptoms (Parry et al.,1995). Two important Fusarium species present in Australia are Fusarium pseudograminearum (Fp), most commonly associated with FCR and Fusarium graminearum (Fg) which causes FHB. FCR in particular, can cause significant yield losses in sub-optimal cereal rotations during dry grain-filling periods in parts of Australia (Alahmad et al., 2018). FCR is also emerging as an important disease internationally (Smiley et al., 2005a, 2005b). It occurs in most cereal-producing regions of the world and has been reported in Australia (Wildermuth et al., 1997; Burgess et al., 2001), Europe (Rossi et al. 1995; Pettitt and Parry 2001), North America (Fernandez and Zentner 2005; Smiley et al. 2005b), South America (Burgess et al. 2001),West Asia and North Africa (Braun et al. 2004; Nicol et al. 2004) and South Africa (Lamprecht et al., 2006, VanWyk et al., 1987). Recently, natural infections of FCR reduced the winter wheat yield by $35 \%$ in commercial fields of the Pacific North-West of the USA; field inoculation with $F$. pseudograminearum in this region demonstrated potential yield losses up to 61\% (Smiley et al., 2005b). Annual losses due to FCR in Australia are estimated at $\$ A 80$ million (Murray \& Brennan, 2009). Crown rot was first recorded in Australia in 1951 although the cause was unknown (McKnight and Hart, 1966). During the 1960s, the pathogen associated with crown rot was described as Fusarium graminearum Schwabe (McKnight and Hart, 1966; Purss, 1966) and later as Fusarium pseudograminearum (Aoki and O'Donnell, 1999). FHB is significant in vast wheat areas of the world with recent epidemics reported in Canada, China, Europe, South America and the USA (McMullen et al., 1997; Goswami and Kistler 2004), prompting the establishment of 
coordinated research and development initiatives in most affected areas. FHB is sporadic in Australia and restricted geographically to areas in northern New South Wales and Queensland (Obanor et al., 2013) during wetter than average seasons. Crop losses in Australia from FHB are difficult to estimate due to its sporadic occurrence, but reliable data are available elsewhere. During 1998-2000, FHB inflicted an estimated US\$2.7 billion loss attributed to reduced yield and price discounts from lower grain quality in the northern Great Plains and central USA (Goswami and Kistler, 2004).

Investigations on isolates of F. graminearum Schwabe established two distinct populations or groups of $F$. graminearum Schwabe (Francis and Burgess, 1977): Group 1 caused crown rot in wheat and Group 2 stalk rot of maize and head blight of wheat. The pathogen associated with crown rot was then identified as F. graminearum Group 1 (Fg G1). The existence of these specific sub-groups was further confirmed by genotyping the pathogen using restriction fragment length polymorphism (RFLP) (Benyon et al., 1995). Further morphological and DNA studies of Group 1 and Group 2 strains from different geographical regions showed that the Group 1 isolates were a distinct species; now designated $F$. pseudograminearum sp nov (Fp) (Aoki and O'Donnell, 1999).

$\mathrm{Fp}$ has been reported in Australia in New South Wales and Queensland, the USA, Argentina and South Africa (Carranza, 1961; Cook, 1968; Van Wyk et al., 1988). Damage caused by Fp in spring and winter cereals is most apparent when whiteheads appear shortly before maturity leading to a high frequency of shriveled grains after harvest. Damage can be highly variable within fields and can reduce yield by $35 \%$. Both FHB and FCR result in the accumulation of mycotoxins in the grain (Desjardins, 2006; Mudge et al., 2006). Increased levels of the trichothecenes nivalenol (NIV) and deoxynivalenol (DON) and other mycotoxins from FHB infection can render the grain and grain products unsafe for human and animal consumption. Zinc deficiency in cereals is widespread and poses a threat to sustainable production (Graham et al., 1992; Takkar and Walker, 1993). Dang et al., (2010) found that the concentration and accumulation of $\mathrm{Zn}$ in all wheat tissues was high during early and middle growing periods, while accumulation of $\mathrm{Zn}$ in grains during late growth primarily depended on redistribution from other organs. Accordingly, it was concluded that $\mathrm{Zn}$ should be applied as a seed dressing or basal fertilizer to accelerate early growth and $\mathrm{Zn}$ absorption in wheat. This paper examines wheat genotypic responses to FCR and FHB diseases and the impact of $\mathrm{Zn}$ fertilizer on disease expression.. To the best of our knowledge, no previous experiments of zinc applications and their interaction with wheat Fusarium pathogens have been conducted, so the present study was designed to assess the Zinc effects on the progress of Fusarium crown rot and Fusarium head blight depending on disease severity as well as protein profile analysis of several wheat cultivars (resistance and susceptible cultivars).

\section{Results}

\section{The response of wheat genotypes to inoculation with FCR under different levels of zinc}

All four wheat genotypes showed significantly different crown rot disease responses at different zinc treatments (Figure 1).
The wheat variety Sunco and CIMMYT 146 were rated more tolerant to disease than Batavia and CIMMYT 48. The addition of zinc significantly increased the tolerance of the crown rot susceptible genotypes Batavia and CIMMYT 48 to crown rot.

\section{The response of wheat genotypes to inoculation with FHB under different levels of zinc}

A differential response of the four wheat genotypes to inoculation with FHB under three zinc levels was observed (Figure 2). A significant increase in the FHB tolerance of Sunco and CIMMYT 146 was evident; however, no change in the responses of Batavia and CIMMYT 48 was observed.

\section{Protein profiling of wheat genotypes inoculated with FCR and FHB at different levels of zinc}

An equal quantity of protein was extracted from all grain samples and subsequently evaluated using SDS-PAGE analysis. Several proteins were expressed differentially, in particular in the molecular mass range of $30-45 \mathrm{kDa}$, under high $\mathrm{Zn}$ that were either not present or less well expressed under low $\mathrm{Zn}$ (Figure 3). The expression level of these proteins was different among the genotypes and treatments evaluated. Batavia and CIMMYT 146 showed maximum up-regulation of the aforementioned proteins at high $\mathrm{Zn}(2 \mathrm{~g} / \mathrm{kg}$ soil), irrespective of disease inoculation with FHB. However, these specific proteins were upregulated in Sunco following $\mathrm{FHB}$ inoculation at intermediate and high levels of $\mathrm{Zn}$ ( $1 \mathrm{~g}$ and $2 \mathrm{~g} / \mathrm{kg}$ soil). CIMMYT 48 showed maximum up-regulation of these proteins at high $\mathrm{Zn}(2 \mathrm{~g} / \mathrm{kg}$ soil) without FHB inoculation.

Discussion

Zinc deficiency in cereals is widespread and a threat to sustainable production (Graham et al., 1992; Takkar and Walker, 1993). Unlike micronutrients, $\mathrm{Zn}$ deficiency is a common feature in both cold and warm climates irrespective of soil pH and texture (Graham et al., 1992). Crown rot disease in wheat is a widespread problem in the chronically $\mathrm{Zn}$ deficient soils of Australia. A link between FCR and Zn deficiency was established by Sparrow and Graham, (1988) and $\mathrm{Zn}$-efficient wheat cultivars that scavenge $\mathrm{Zn}$ from $\mathrm{Zn}$-deficient soils tend to express better resistance to pathogens (Grewal et al., 1996). Zinc inefficient cultivars tend to require extra $\mathrm{Zn}$ fertilization to maintain performance comparable to more $\mathrm{Zn}$ efficient materials.

In the current study, Sunco and CIMMYT 146 are Zn efficient and better able to maintain resistance to both Fusarium diseases in the absence of $\mathrm{Zn}$ fertilization. However, the FCR susceptible genotypes Batavia and CIMMYT 48 required $\mathrm{Zn}$ fertilization to express even a low level of resistance to both pathogens. The current study suggests that Zn-efficient cultivars of wheat, combined with crown rot resistance, will enhance wheat performance in $\mathrm{Zn}$-deficient soils prone to FCR. The judicious use of $\mathrm{Zn}$ fertilizer may also reduce the severity of the disease regardless of the resistance of the wheat cultivar. .

The four wheat genotypes also exhibited a differential response to inoculation with FHB. However, the application of $\mathrm{Zn}$ enhanced the tolerance of Sunco and CIMMYT 146 to the 
Table 1. The scores of disease severity.

\begin{tabular}{lccccccc}
\hline $\begin{array}{l}\text { FCR disease } \\
\text { severity }\end{array}$ & No Zinc & $1 \mathrm{~g} / \mathrm{kg}$ soil & $2 \mathrm{~g} / \mathrm{kg}$ soil & $\begin{array}{c}\text { FHB disease } \\
\text { severity }\end{array}$ & No Zinc & 1g/kg soil \\
\hline Batavia & 3.65 & 1.2 & 0.75 & Batavia & 4.0 & 4.0 & 4.0 \\
Sunco & 1.3 & 0.55 & 0.2 & Sunco & 3.7 & 2.7 & 2.0 \\
146 & 0.9 & 0.5 & 0.3 & 146 & 3.6 & 3.6 & 2.5 \\
48 & 2.7 & 1.55 & 0.5 & 48 & 4.0 & 4.0 \\
\hline
\end{tabular}

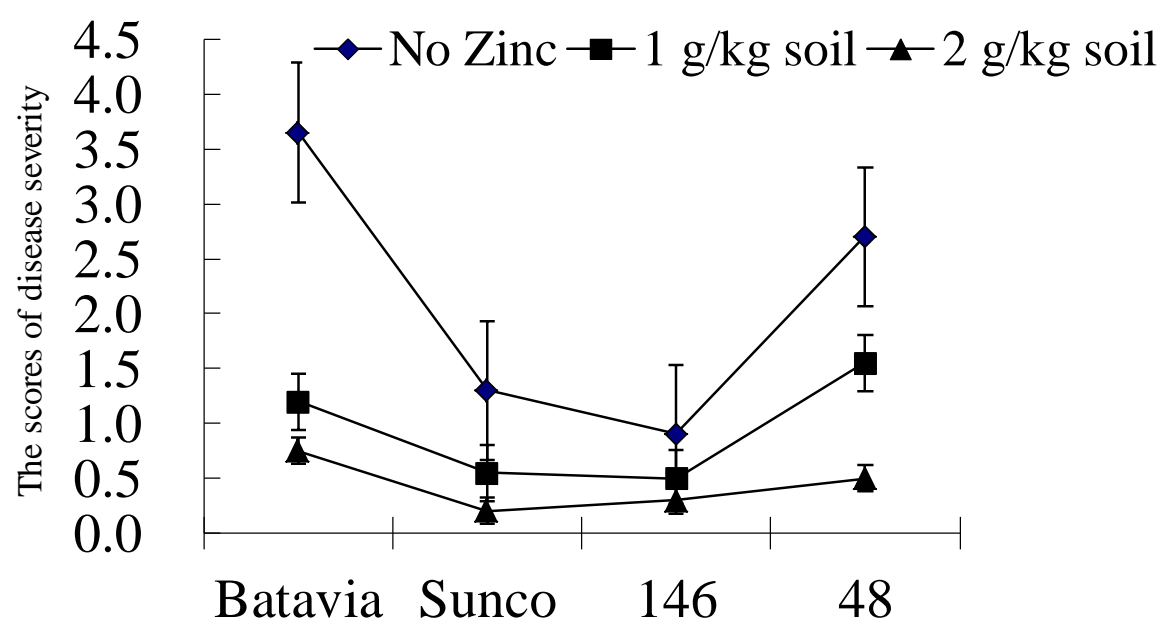

Genotypes

Fig 1. The change in resistance of four wheat genotypes to crown rot disease under zinc levels of 0,1 and $2 \mathrm{~g}$ per $\mathrm{kg}$ of soil.

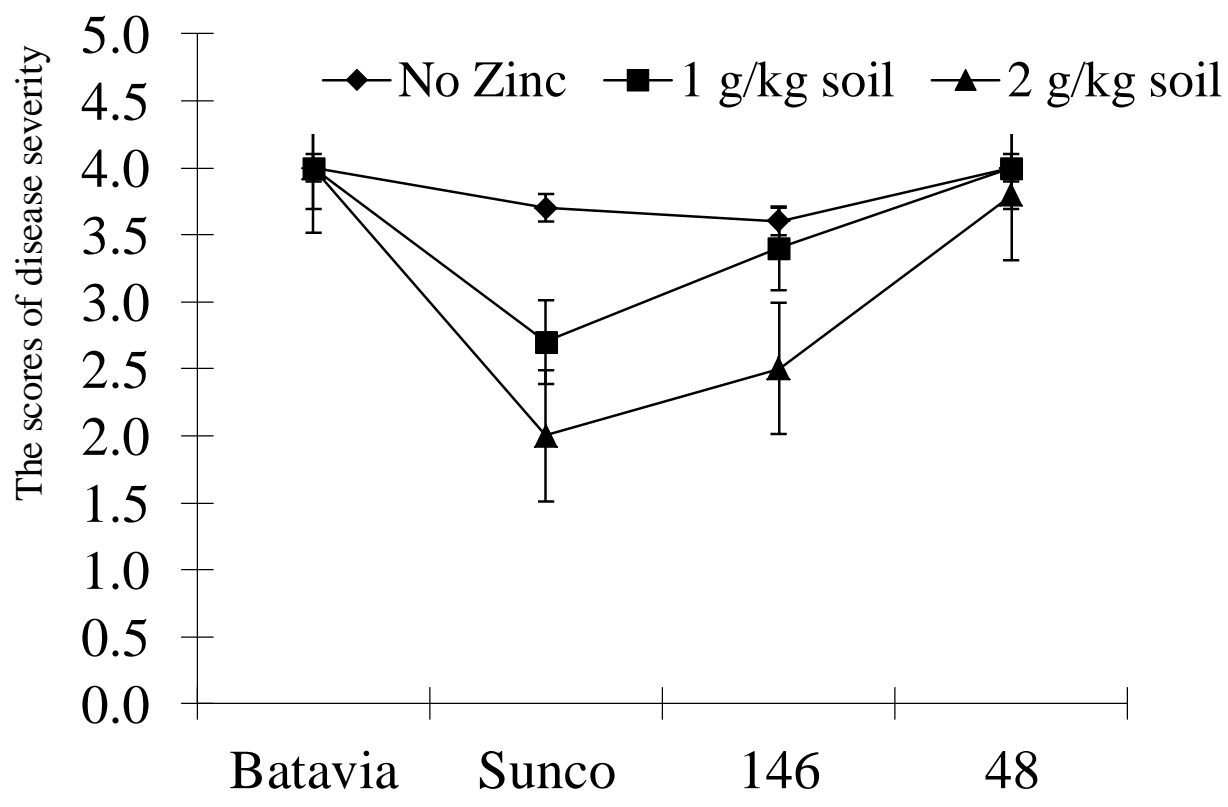

Genotypes

Fig 2. The change in resistance of four wheat genotypes to Fusarium head blight under zinc levels of $0,1 \mathrm{and} 2 \mathrm{~g}$ per kg of soil. 

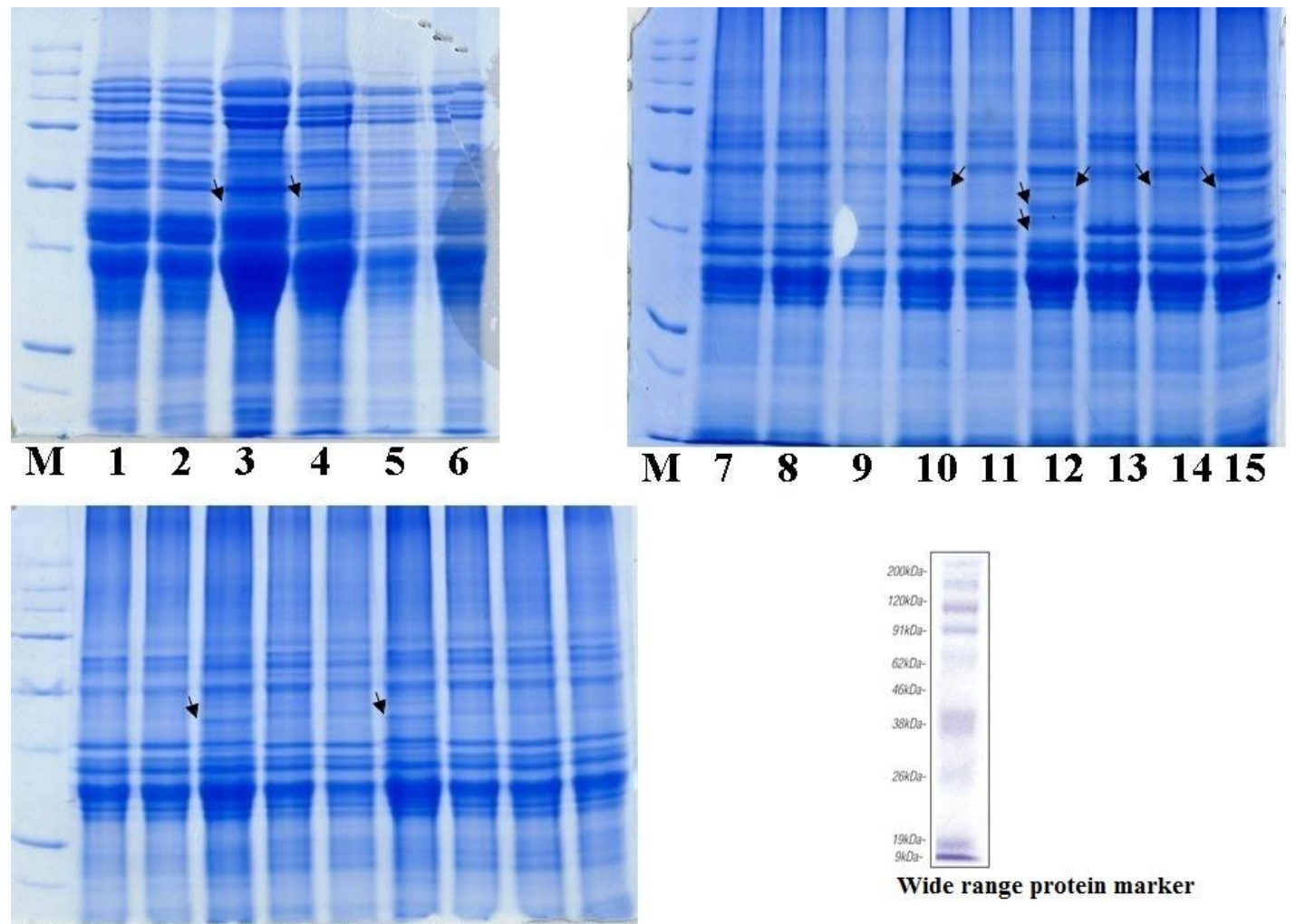

Wide range protein marker

\section{161718192021222324}

Fig 3. Protein profile of different wheat genotypes. Batavia (B)+no disease inoculation (NDI)+Zinc $1 \mathrm{~g} / \mathrm{kg}$ of soil $(\mathrm{Zn} 1) ; 2$, $B+N D I+N o$ Zinc $(\mathrm{ZnO}) ; 3, \mathrm{~B}+\mathrm{NDI}+\mathrm{Zinc} 2 \mathrm{~g} / \mathrm{kg}$ of soil $(\mathrm{Zn2}) ; 4$, B+disease inoculation (DI)+Zn 2; 5, B+DI+ Zn0; 6, B+DI+Zn1; 7, Sunco (S)+NDI+Zn0; 8, S+NDI+Zn1; 9, S+NDI+Zn2; 10, S+DI+Zn1; 11, S+DI+Zn0;12, S+DI+Zn2;13,146+NDI+Zn0;14, 146+NDI+Zn1; 15, 146+NDI+Zn2;16, 146+DI+Zn0; 17, 146+DI+Zn1; 18, 146+DI+Zn2; 19, 48+NDI+Zn0; 20, 48+NDI+Zn1; 21, 48+NDI+Zn2; 22, 48+DI+Zn2; 23, 48+DI+Zn1; and $24,48+\mathrm{DI}+\mathrm{ZnO}$.

disease, while Batavia and CIMMYT 48, both susceptible to FHB, did not express improved disease resistance to $\mathrm{Zn}$ inoculation. These later two genotypes did show a response to $\mathrm{Zn}$ under FCR but this was not evident for FHB. It may be that the level of susceptibility to FHB in Batavia and CIMMYT 48 was so high that minor impacts attributable to $\mathrm{Zn}$ nutrition simply disappeared.

Zinc is an essential micronutrient for many vital metabolic processes in plants and an important cofactor for several enzymes (Aravind and Prasad, 2003). As Zn application increased the FHB resistance of $\mathrm{Zn}$ efficient wheat genotypes, it may also require a much higher level of $\mathrm{Zn}$ fertilization to elicit a positive response in less $\mathrm{Zn}$ efficient genotypes.

Zinc is known to have a stabilizing and protective effect on bio-membranes against oxidative and peroxidative damage, loss of plasma membrane integrity and alteration of the permeability of the membrane. This effect may also reduce the impact of Fusarium toxins on plant cells and the effect of fusaric acid on plasma membrane integrity (Brion et al, 1997).

Protein profiling revealed several differentially expressed proteins in the 30-45 kDa range under $\mathrm{Zn}$ application (Figure 3). Proteins of this molecular size are wall-associated kinase 4-like proteins, isoflavone reductase, oxygenase activase 2, chloroplastic and chloride carrier (Shin et al., 2011). These proteins play an important role in plant responses to disease and mineral imbalances (Shin et al., 2011). Sunco showed an additional band with an approximate molecular weight of 35 $\mathrm{kDa}$ at high $\mathrm{Zn}$ levels ( $2 \mathrm{~g} / \mathrm{kg}$ soil) following disease inoculation. This band may correspond to a defense protein; cytochrome $c$ oxidase (Shin et al., 2011).

The disease reducing effects of $\mathrm{Zn}$ application has been reported for a range of fungal pathogens in many crops including cotton, rice and banana (Agrios, 1988; Marino et al., 2003). However, our results are showed the suppression of $F C R$ and FHB in wheat. If genetic resistance is combined with genetic $\mathrm{Zn}$-efficiency or $\mathrm{Zn}$ application through management, then the expression and impact of these important Fusarium diseases is likely to reduce.

\section{Materials and Methods}

\section{Plant material and growth conditions}

Four wheat genotypes; Batavia, Sunco, CIMMYT line 146 and CIMMYT line with three replication for each treatment, were evaluated for response to FHB and crown rot under different levels of $\mathrm{Zn}$ application (Table 1). Wheat genotypes were grown in $15 \mathrm{~cm}$ plastic pots filled with potting mixture comprising 8 parts composted pine bark and 2 parts coarse sand. Three levels of $\mathrm{Zn}$ treatment were imposed: 0,1 \& 2 $\mathrm{g} / \mathrm{kg}$ of soil applied as pellets one week after planting. The pots were then placed in a greenhouse set at 18 to $20^{\circ} \mathrm{C}$. 


\section{Pathogenicity test}

One monosporic isolate of Fusarium pseudograminearum was tested for pathogenicity after one week of germination. Seedling inoculation was conducted using an agar plug of 5 $\mathrm{mm}$ diameter infected with actively growing $\mathrm{Fp}$ mycelium placed as close as possible to the root system. The soil surface of the pot was then covered with a thin layer of wheat bran to promote infection. Control plants were treated similarly but without fungal inoculation. Crown rot symptoms were evaluated and recorded 90 days post-planting. The disease severity was recorded according to the following scale:

$1=$ slight brown discoloration of the upper root system

$2=$ moderate brown discoloration of two-thirds or less of the upper

3 = extreme brown discoloration of the upper root system and numerous necrotic lesions extending up the crown and stem 4 = Plant death

A score of $1<3$ was considered resistant to moderately resistant and $3-4$ susceptible.

Symptoms for FHB were scored at maturity using a scale 0-4 where $0=$ no disease expression and 4 highly susceptible.

\section{Protein profiling of wheat different cultivars in response to $\mathrm{Zn}$ application and Fusarium infection}

Total protein was extracted from SDS-PAGE analysis according to the TCA-acetone method (Granier, 1988). Protein concentration was determined using the Coomassie method (Bradford 1976) and total protein was separated by SDS-PAGE based on the method described by Laemmli, (1910). The amount of protein loaded for each sample was $50 \mathrm{pg}$ and gels were repeated at least three times for each sample to confirm reproducibility. Gels were stained with colloidal Coomassie blue stain and examined for differences in protein expression among the different treatments for each genotype. Gels were scanned using a densitometer (Bio-Rad GS-800) and bands of interest were identified by estimating size/mass relative to the $2 \mathrm{kD}$ wide range protein marker.

\section{Statistical analysis}

The complete randomized design was used with four replicates for each treatment. The obtained data was analysed according to one way analysis of variance (ANOVA), the mean treatments were compared with Least Significant Difference (LSD) test at the probability level of 0.01 , statistical analysis was done by using the SPSS-22 statistical software (SPSS In., Chicago, IL., USA) version 22 .

\section{Conclusion}

Our results highlighted the efficiency of Zinc application at different concentrations ( 1 and $2 \mathrm{mg} / \mathrm{Kg}$ soil) on Wheat responses to Fusarium head blight and Fusarium crown rot diseases in four wheat genotypes which were Batavia, Sunco, CIMMYT line 146 and CIMMYT line 48. Results revealed that $\mathrm{Zn}$ application led to a significant enhancement of $\mathrm{Zn}$ - efficient genotypes Batavia and CIMMYT line 48 to Fusarium crown rot disease compared to Sunco and CIMMYT line 146; different trend of responses were observed in Fusarium head blight disease with significant increase in the FHB tolerance of Sunco and CIMMYT 146. Protein profile analysis of different wheat genotypes to the infection with $\mathrm{F}$. pseudograminearum and $\mathrm{F}$. graminearum pathogens showed different patterns of protein expressions, in particular in the molecular mass range of 30-45 $\mathrm{kDa}$ as a response to $\mathrm{Zn}$ treatment at high concentration (2 $\mathrm{mg} / \mathrm{Kg}$ soil) compared with low concentration. Future research could be carried out to examine another concentrations of $\mathrm{Zn}$ on different wheat genotypes as well as examining the interaction between macro and micronutrients status in plant on Zn efficiency.

\section{Acknowledgement}

Authors acknowledge the contributions made by the staff and students of the Plant Breeding Institute, The University of Sydney for their help during these studies and providing the germplasm.

\section{References}

Agrios GN (1988) Plant Pathology, 3ed. Academic rd Press Inc., San Diego U.S.A.

Alahmad S, Simpfendorfer S, Bentley AR, Hickey LT (2018) Crown rot of wheat in Australia: Fusarium pseudograminearum taxonomy, population biology and disease management. Australasian Plant Pathology. 1;47(3):285-99.

Aoki T and O'Donnell K (1999) Morphological characterization of Gibberella coronicola sp. nov., obtained through mating experiments of Fusarium pseudograminearum. Mycoscience 40: 443-453.

Aravind P, Prasad, MNV (2003) Zinc alleviates cadmium induced toxicity in Ceratophyllum demersum, a fresh water macrophyte. Plant Physiol. and Biochem. 41: 391-397.

Bentley AR, Griffiths SP, Burgess LW and Summerell BA (2004) Austrostipa aristiglumis (Plains grass) as an Intermediate.

Benyon F, Burgess L and Sharp P (1995) Molecular Variation Amongst Fusarium species Responsible for Crown Rots of Winter Cereals in Relation to their Pathogenicity and Morphological Characteristics. In: International Seminar on Fusarium: Mycotoxins, Taxonomy and Pathogenicity, Martina Franca.

Brion KD and Geneviève D (1997) Zinc Improves Biocontrol of Fusarium Crown and Root Rot of Tomato by Pseudomonas fluorescens and Represses the Production of Pathogen Metabolites Inhibitory to Bacterial Antibiotic Biosynthesis Phytopathology Group, Institute for Plant Sciences, Swiss Federal Institute of Technology, Universitätstrasse 2, $\mathrm{CH}$ 8092, Zürich.

Braun HJ, Mergoum M, Morgounov A, Nicol J (2004) Adaptation of winter wheat to central and west Asia.CIMMYT research results. Available at http://www.cimmyt.org/research/wheat/map/researchesult s/reshighlights/pdfs/reshigh adaptwinter.pdf (verified 13 September 2006).

Burgess LW, Backhouse D, Summerell BA, Swan LJ (2001) Crown rot of wheat. In 'Fusarium: Paul E. Nelson memorial symposium'.(Eds BA Summerell, JF Leslie, D Backhouse, WL 
Bryden, LW Burgess) pp. 271-294. (The American Phytopathological Society: St Paul, MN).

Burgess LW, Backhouse D, Summerell BA and Swan LJ (2001) Crown Rot of Wheat. In: Fusarium: Paul E. Nelson Memorial Symposium (Summerell BA, Leslie JF, Backhouse D, Bryden WL, et al., eds.). American Phytopathological Society Press, Saint Paul, 271-294.

Carranza T (1961) Root decay and blight of cereals in Argentina caused by Gibberella zeae (Fusarium graminearum).

Cook R (1968) Fusarium root and foot rot of cereals in the Pacific Northwest. Phytopathology. 58, 127-131.

Dang H-K, LI Rui-Qi, Sung Y-H, Zhang X-W and Li Y-M (2010) Absorption, Accumulation and Distribution of Zinc in HighlyYielding Winter Wheat. Agricultural Sciences in China. 9(7): 965-973.

Desjardins AE (2006) Fusarium Mycotoxins: Chemistry, Geneticsand Biology. St Paul, MN, USA: APS Press.

Fernández-Falcón M, Borges AA, Borges-Pérez Andres (2003) Induced resistance to Fusarium wilt of banana by exogenous applications of indoleacetic acid. Phytoprotec. 84 : 149-153.

Fernandez MR, Zentner RP (2005) The impact of crop rotation and $\mathrm{N}$ fertilizer on common root rot of spring wheat in the Brown soilzone of western Canada. Canadian Journal of Plant Science. 85,569-575.

Francis RG and Burgess L (1977) Characteristics of two populations of Fusarium roseum 'Graminearum' in Eastern Australia. Trans Br Mycol Soc. 68: 421-427.

Góral T, Wiśniewska H, Ochodzki P, Nielsen L, Walentyn-Góral $D$, Stępień $Ł$ (2019) Relationship between Fusarium Head Blight, Kernel Damage, Concentration of Fusarium Biomass, and Fusarium Toxins in Grain of Winter Wheat Inoculated with Fusarium culmorum. Toxins. 11(1):2.

Goswami RS, Kistler HC (2004) Heading for disaster: Fusarium graminearum on cereal crops. Molecular Plant Pathology. 5:515-525.

Graham RD, Ascher JS, Hynes SC (1992) Selecting zinc-efficient cereal genotypes for soils of low zinc status. Plant and Soil. 146, 241-250.

Grewal HS, Graham RD, Rengel Z (1996) Genotypic variation in zinc efficiency and resistance to crown rot disease (Fusarium graminearum Schw. Group 1) in wheat. Plant and Soil. 186: 219-226.

Jin SB (1996) China Wheat Science. China Agriculture Press, Beijing. pp. 180-181. (in Chinese).

Lamprecht SC, Marasas WFO, Hardy MB, Calitz FJ (2006) Effectof crop rotation on crown rot and the incidence of Fusarium pseudograminearum in wheat in the Western Cape, South Africa. Australasian Plant Pathology. 35, 419-426.

McKnight T and Hart J (1966) Some field observations on crown rot disease of wheat caused by Fusarium graminearum.Queensl. J Agr Anim Sci. 23: 373-378.

McMullen M, Jones R, Gallenberg D (1997) Scab of wheat and barley:A re-emerging disease of devastating impact. Plant Disease. 81:1340-1348.

Mishra PK, Tewari JP, Clear RM and Turkington TK (2006) Genetic diversity and recombination within populations of Fusarium pseudograminearum from western Canada. Int Microbiol. 9: 65-68.

Mitter V, Zhang M, Liu C, Ghosh R (2006) A high throughput glasshouse bioassay to detect crown rot resistance in wheat germplasm. Plant Pathol. 55: 433-441.
Memorial Symposium (Summerell BA, Leslie JF, Backhouse D, Bryden WL, et al., eds.). American Phytopathological Society Press, Saint Paul, 271-294.

Mudge AM, Dill-Macky R, Dong Y, Gardiner DM, White RG, Manners JM (2006) A role for the mycotoxin deoxynivalenol in stem colonization during crown rot disease of wheat caused by Fusarium graminearum and Fusarium pseudograminearum. Physiological and Molecular Plant Pathology. 69, 73-85.

Murray G, Brennan J(2009) Estimating disease losses to the Australian wheat industry. Australasian Plant Pathology. 38:558-70.

Nicol JM, Bagci A, Hekimhan H, Bolat N, Braun HJ, Trethowan R (2004) Strategy for the identification and breeding of resistance to dryland root rot complex forlnternational spring and winter wheat breeding programs.In 'Proceedings of the 4th International Crop Science Congress'.

Obanora F, Neateb S, Simpfendorferc S, Sabburga R, Wilsondand P, Chakrabortya S (2013) Fusarium graminearum and Fusarium pseudograminearum caused the 2010 head blight epidemics in Australia Plant Pathology. 62:79-91.

Parry DW, Jenkinson P, McLeod L (1995) Fusarium ear blight (scab) in small grain cereals-a review. Plant pathology. 44(2):207-38.

Peterson CJ, Johnson VA, Mattern PJ (1986) Influence ofcultivar and environment on mineral and protein concentrations of wheat flour, bran, and grain. Cereal Chemistry. 63, 183-186.

Pettitt TR, Parry DW (2001) Effect of temperature on Fusarium foot rot of wheat. In 'Fusarium: Paul E. Nelson memorial symposium'. (Eds BA Summerell, JF Leslie, D Backhouse, WL Bryden, LW Burgess) pp. 145-160. (The American hytopathological Society: St Paul, MN)

Purss G (1966) Studies of varietal resistance to crown rot of wheat caused by Fusarium graminearum Schw. Queensland Journal of Agricultural and Animal Sciences. 23:475-598.

Ranjbar GA, Bahmaniar MA (2007) Effect of soil and foliar application of $\mathrm{Zn}$ fertilizer on yield and growth characteristics of bread wheat (Triticum aestivum L.) cultivars. Asian Journal of Plant Science.6(6).

Rossi V, Cervi C, Chiusa G, Languasco L (1995) Fungi associated with foot rots on winter wheat in northwest Italy. Journal of Phytopathology. 143, 115-119.

Seilsepour M (2006) Study of zinc effects on quantitative and qualitative traits of winter wheat in saline soil condition. BIABAN (Desert Journal). 11, 17-23.

Shin KH, Kamal AHM, Cho K, Choi JS, Jin Y, Paek NC, Lee YW, Lee JK, Park JC, Kim HT, Heo HY, Woo S (2011) Defense proteins are induced in wheat spikes exposed to Fusarium graminearum. Plant Omics. 4: 270-277.

Smiley RW, Gourlie JA, Easley SA and Patterson LM (2005) Crop damage estimates for crown rot of wheat and barley in the Pacific Northwest. Plant Dis. 89: 595-604.

Smiley RW, Gourlie JA, Easley SA, Patterson L-M (2005a) Pathogenicity of fungi associated with the wheat crown rot complex in Oregon and Washington. Plant Disease. 89: 949957.

Smiley RW, Gourlie JA, Easley SA, Patterson L-M, Whittaker RG (2005b) Crop damage estimates for crown rot of wheat and barley in the Pacific Northwest. Plant Disease. 89: 595-604. 
Takkar P, Walker CD (1993) The distribution and correction of zinc deficiency. Developments in Plant and Soil Sciences. 55: 151-151.

Van Wyk P, Los O, Marasas W (1988) Pathogenicity of a new Fusarium sp. from crown rot of wheat in South Africa. Phytophylactica. 20, 73-75.

VanWyk PS, Los O, Pauer GDC and Marasas WFO (1987) Geographic distribution and pathogenicity of Fusarium species associated with crown rot of wheat in the Orange Free State, South Africa. Phytophylactica. 19: 271-274.

Wildermuth G, McNamara R (1994) Testing wheat seedlings for resistance to crown rot caused by Fusarium graminearum. Group 1. 949-953.
Wildermuth GB, Thomas GA, Radford BJ, McNamara RB, Kelly $A(1997)$ Crown rot and common root rot in wheat grown under different tillage and stubble management treatments in southern Queensland, Australia. Soil and Tillage Research. 44, 211-224.

Wildermuth G, Purss G (1971) Further sources of field resistance to crown rot (Gibberella zeae) of cereals in Queensland. Australian Journal of Experimental Agriculture and Animal Husbandry. 11, 455-459. 